\title{
Technical and Economic Feasibility Studies of a Micro Hydropower Plant in Cameroon for a Sustainable Development
}

\author{
Elie Bertrand Kengne Signe ${ }^{1,2 *}$, Oumarou Hamandjoda1, Jean Nganhou1, Laure Wegang3 \\ ${ }^{1}$ L3E, National Advanced School of Engineering of University of Yaoundé1, Yaoundé, Cameroon \\ ${ }^{2}$ Laboratory of Energy Research, Institute for Geological and Mining Research, Yaoundé, Cameroon \\ ${ }^{3}$ Teacher's Training College of Technical Education University of Douala, Douala, Cameroon \\ Email: *kengne82@yahoo.fr
}

How to cite this paper: Kengne Signe, E.B., Hamandjoda, O., Nganhou, J. and Wegang, L. (2017) Technical and Economic Feasibility Studies of a Micro Hydropower Plant in Cameroon for a Sustainable Development. Journal of Power and Energy Engineering, 5, 64-73.

https://doi.org/10.4236/jpee.2017.59006

Received: August 3, 2017

Accepted: September 12, 2017

Published: September 15, 2017

Copyright () 2017 by authors and Scientific Research Publishing Inc. This work is licensed under the Creative Commons Attribution International License (CC BY 4.0).

http://creativecommons.org/licenses/by/4.0/

\section{(c) (i) Open Access}

\begin{abstract}
All serious projects over the world should respect the objectives of sustainable development. The contribution of every country against the climate change is request applied. The development of renewable energies is an effective contribution to solutions for this relevant question. Hydropower energy is one of most promising clean energy technologies. However, Micro Hydro Power Plants (MHPP) will be more promising than large hydro power stations. Cameroon has a great hydroelectric potential, but the access rate to electricity is still very low in rural areas of this country. The objective of this work is to do the technical and economic assessment of a MHPP in BAKASSA, which is a remote village in the West Region of Cameroon, in the intention to contribute to its sustainable development. The results of this study show that this MHPP project can be developed with installed power of $97 \mathrm{~kW}$, where the Francis turbine is

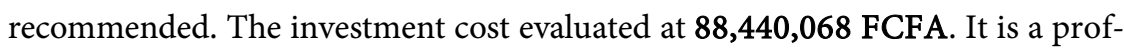
itable project with a maximum payback period of 9 years.
\end{abstract}

\section{Keywords}

Feasibility Studies, Micro Hydro, Sustainable Development

\section{Introduction}

One of the reasons that greenhouse gas emissions were increasing is fossil fuels consumption. To reduce fossil fuel consumption, many countries have developed renewable energy technologies. Cameroon also intends to develop and integrate lots of renewable energies for the efficiency of its energy system. 
The rate of access to electricity in Cameroon was $49 \%$ in 2012, which less than $20 \%$ in the rural area [1]. Since some years, the State tries to improve this rate particularly in rural area, with also the promotion of renewable sources. Wind resources in this country are quite poor (less than $4 \mathrm{~m} / \mathrm{s}$ ) and are inconsistent over the year [2]. Wind energy is therefore not a feasible energy supply option. Solar energy resources, although abundant in this Country, cannot be developed alone due to the limited number of cloudless days per year.

However, that country has significant hydroelectric potential. But only large power plants are often developed, leaving out many other sites favorable to the implantation of MHPP, able to satisfy the needs of electrification in the remote rural areas and thus contribute to their sustainable development. The aim of this study is to develop the feasibility studies of a MHPP project in the West Region of Cameroon, on a fall river of BAKASSA.

\section{Micro Hydro Power Plant System}

The hydropower plant is a system of power generating based on the principle that flowing and falling water has a certain amount of kinetic energy potential associated with it. Hydropower comes from converting the energy in flowing water, by means of a water wheel or a turbine, into useful mechanical energy. This energy can then be converted into electricity through means of an electric generator. The energy from the flowing/falling water can also be used directly by suitable machines to avoid the efficiency loses of the generator. Actually in the world MHPP receive a public interest as a promising, renewable source of electrical power for homes, farms, and remote communities. There is not yet a universal classification of hydro power plant according to the power generating. This classification varies from a country to another [3]. In the Cameroon case and in this study, we will consider that a small scale hydropower system is called micro hydro, which can generate power up to $1000 \mathrm{~kW}$.

The MHPP system includes a water turbine that converts the energy of flowing water into mechanical energy. This mechanical energy drives a generator which produces electrical power. The efficiency of the overall system, given the pipe friction loses and turbine deficiencies, is generally on the range of $50 \%$ of theoretical power associated with the energy of the flowing water. Micro-hydro has been in use for many years in many applications. The turbine varies from site to site according to the given pressure head and design flow at each site [4]. The Figure 1 below shows a typical system and details components generally found at a micro-hydro facility.

Water flow in upstream will be diverted in intake weir and it will flow into the channel. The channel transports the water to fore bay tank before going to penstock pipe. In the tank, debris will be filtered and prevented from being drown to the turbine by means of penstock. Power conversion is done inside the power house, and turbine will transfer mechanic energy to generator, then generator produces electric energy. 


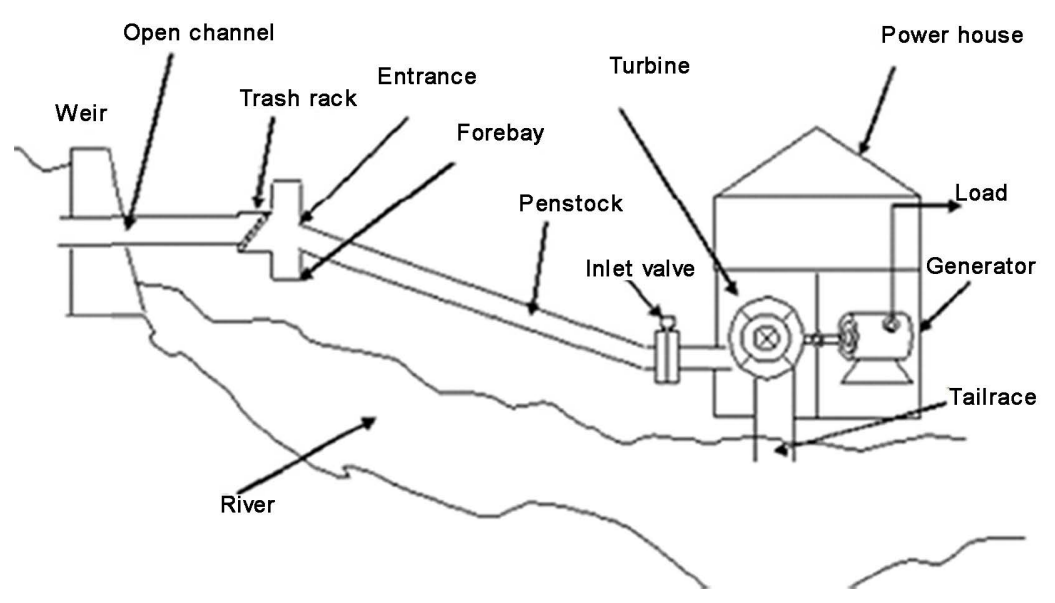

Figure 1. A typical system and details components of a MHPP.

\section{Materials and Methods}

\subsection{Study Site and Materials}

BAKASSA is a river in Bansoa District, Menoua Division and West Region of Cameroon. Located in between $5^{\circ} 26^{\prime} 54^{\prime \prime N}$ North, $10^{\circ} 18^{\prime} 49^{\prime \prime}$ East [5]. BAKASSA has good water supply to be used for MHPP, and in this study a feasibility study for its implementation will be done. The following Figure 2 shows a photo of waterfall in study.

Software of feasibility studies of MHPP developed for local need, electronic laser level with Global Positioning Systems (GPS), questionnaire series, length meters, hydrological data and several other documents were used.

\subsection{Methods}

\subsubsection{The Gross Waterfall Height}

The gross waterfall height is the altitude difference between the upstream and downstream water levels of the waterfall. Lots of recognitions visits were done. The gross fall height was measured using an electronic laser level with a suitable accuracy. It is a topographic datum which can also be measured thanks to a map for high falls.

\subsubsection{The Flow Rate of Equipment}

In the intention to do a good design of MHPP, it is necessary to collect (or simulate with a suitable model) some discharge on waterfall of one year. For an isolate system, the flow rate of equipment used to design the turbine is that which is exceeded 250 days per year [6].

\subsubsection{Technical Elements of MHPP}

A Software, called MASS-Hydro, developed by some local experts was used to calculate and determine technical elements of that micro-Hydro. This software was developed considering conventional calculation of formulas of MHPP characteristics shown below [7]: 


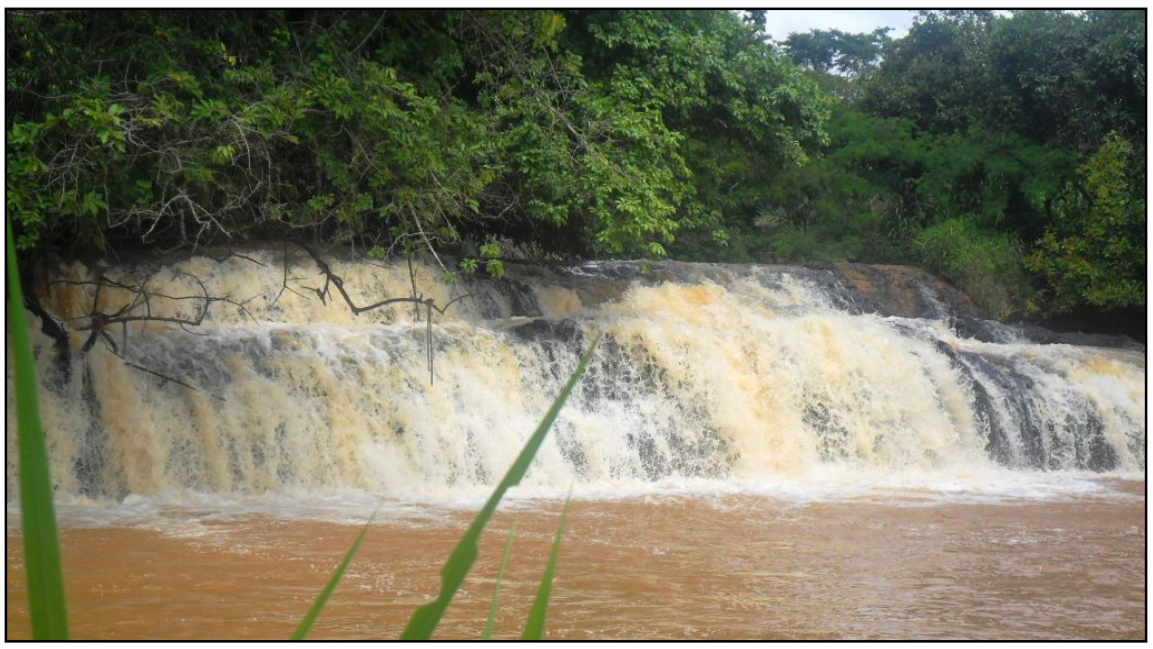

Figure 2. The waterfall of BAKASSA.

\section{1) Installed power generation}

The power generated from hydraulic turbines is a function of the available net head, the flow rate, and the efficiency of the turbine. It can be estimated by:

$$
P=\eta \cdot \rho \cdot g \cdot Q \cdot H
$$

where $P$ is hydro power generation capacity of plant in $\mathrm{kW}, H$ is net head of water in meter, $Q$ is discharge in $\mathrm{m}^{3} / \mathrm{s}, g$ is gravity acceleration constant $(=9.81$ $\left.\mathrm{m} / \mathrm{s}^{2}\right), H_{n}=$ net head $(\mathrm{m})$ and $\eta$ is turbine efficiency $(=80 \%-90 \%)$.

\section{2) Weir}

Several types of notch can be used such as rectangular, Vee or trapezoidal. The material may be metal plate, concrete or hard wood with sharp edges. A simple linear measurement of the difference in level between the up-stream water surface and the bottom of the notch is sufficient to quantify the flow rate. The height takes into account the point of entry of water into the supply pipe.

\section{3) The water intake}

Placed at the inlet of the supply line, the water intake avoids turbulence, stops heavy or light debris with the screen, threshold and chicane. The inlet water level must be below the water level to prevent air from entering the line. The flow rate through it can be given as [2]:

$$
Q=1.8 \times(w-0.2 h) \times h^{1.5}
$$

where, $Q$ is discharge in $\mathrm{m}^{3} / \mathrm{s} w=$ weir width $(\mathrm{m}), h=$ Weir height $(\mathrm{m})$. If $w \geq 3$ $h$, then weir dimensions can be calculated.

\section{4) The supply channel}

Not only, for its stability channel must be a rigid structure and do not permit deformations, but also Channel does not support thrust or up lift pressure. It is recommended to consider that the minimum permissible speeds in the channel are limited to reduce sedimentation, to avoid the erosion of the walls or the bed. These speeds are: $2.49 \mathrm{~m} / \mathrm{s}$ for the steel lining and $3.66 \mathrm{~m} / \mathrm{s}$ for the concrete lining [8]. 


\section{5) Fore bay}

For a good decantation of water before entering the penstock, it is recommended to equip it with a $20 \mathrm{~cm}$ high concrete sill which retains the creeping particles, a screen which overcomes the threshold and stops the other particles, and a deflector which stops the floating debris. The depth of the fore bay varies from 1.50 to $2.50 \mathrm{~m}$ [8].

\section{6) The penstock}

The economic diameter in $(\mathrm{m})$ is calculated using several methods, including the following equation:

$$
D_{p}=2.69 \times\left(n_{p}^{2} \times Q^{2} \times L_{P} / H_{g}\right)^{0.1875}
$$

where, $n_{p}$ is Manning's coefficient $(=0.009-0.011)$ for PVC in example), $Q$ is turbine water flow rate $\left(\mathrm{m}^{3} / \mathrm{s}\right), L_{p}$ is penstock length $(\mathrm{m}), H_{g}=$ gross head $(\mathrm{m})$.

The minimum wall thickness recommended is:

$$
t_{p}=\frac{D_{p}+508}{400}+1.2
$$

where, $D_{p}$ is penstock diameter $(\mathrm{mm}), t_{p}=$ minimum penstock thickness $(\mathrm{mm})$ [7].

\section{7) Electromechanical equipment}

The turbine and generator depend on the characteristics of the Fall River (net head and flow rates). The choice of the turbine is made as a function of the nominal flow rate $Q_{n}$ and the net head $H_{n}$ according to the Sulzer-Escher Wyss diagram [3], as shown in the following Figure 3.

\section{8) The power house}

The turbo-generator equipment and control elements are installed in power house. The dimension can be calculated using the following equations.

$$
\begin{gathered}
L=n(5 d+2.5)+e \\
l>5 d+2.5 \\
2.5>h>2
\end{gathered}
$$

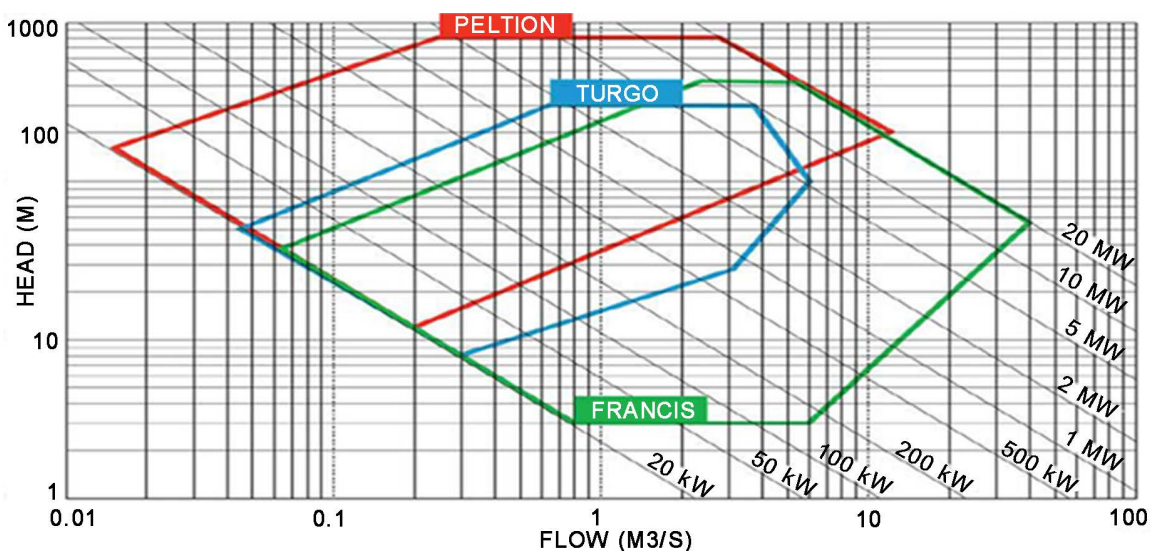

Figure 3. Turbine selection. 
where, $L$ is the length $(\mathrm{m}), l$ is width $(\mathrm{m})$, height $h(\mathrm{~m}), n$ is the number of turbo-generator sets, $d$ is the turbine outlet diameter $(\mathrm{m}), e$ is the length of the loading dock equivalent to the maximum right-of-way of one unit $(\mathrm{m})$ [9].

\section{9) The distribution network}

Grid voltage: For low power and short distances. The experts recommend that, the distribution can be done directly in low voltage, 380/220 Volts with a frequency of $50 \mathrm{~Hz}$.

\subsubsection{Cost and Financial Analyses}

To set up a MHPP, the costs of different element depend on environment constraints and vary from a site to another. Local materials are much recommended to reduce costs. A MHPP can usually operate during around $60 \%$ of time per year, and the operating costs represent $30 \%$ of the cash-flow [8].

1) The net present value (NPV)

Considering that the initial investment cost is $I_{0}$; discount rate is " $a$ "; for years $1,2, \cdots, N$, Cash-flows and Operating costs can be respectively represent by: $C F_{1}, C F_{2}, \cdots, C F_{N} ; C_{1}, C_{2}, \cdots, C_{N}$; the net present value (NPV) of the project is given by the following equation:

The project is profitable if $N P V \geq 0$.

$$
N P V=\sum_{I=1}^{N} \frac{C F_{i}-C_{i}}{(1+a)^{i}}-I_{0}
$$

\section{2) The pay-back period}

It is the time takes for the net present value to be zero.

\section{Results and Discussion}

\subsection{Results}

\subsubsection{The Gross Head and the Flow Rates}

After many measurements, the gross head obtained is 3, $4 \mathrm{~m}$. At less than $1 \mathrm{~km}$ from the BAKASSA waterfall, that river has been gauged by a hydrological station belonging to the Hydrological Research Center of the Institute of Geological and Mining Research in 1985. We obtained the means daily discharges of one year from this institute [10]. The average daily flows rate resulting from the station mentioned above made it possible to plot the curve of the classified discharges presented in the following Figure 4.

\subsubsection{Installed Power and Electrical Energy}

This project will be more efficient for the feeding of a decentralized network. Then, considering the Figure 4 above and the recommendation explained in 3.2.2. of this paper, The MASS-Hydro software give an equipment flow rate of $2,9 \mathrm{~m}^{3} / \mathrm{s}$. Then, $P=96,727, W \approx 97 \mathrm{~kW}$.

So the producible is: $P_{E}=97 \times 8760=849,720 \mathrm{kWh} \approx 850 \mathrm{MWh}$.

\subsubsection{Technical Components Choice}

The weir: Can be built stone and concrete beam. We recommended a trapezoidal type because of the shape of environment. Developers (those working in 


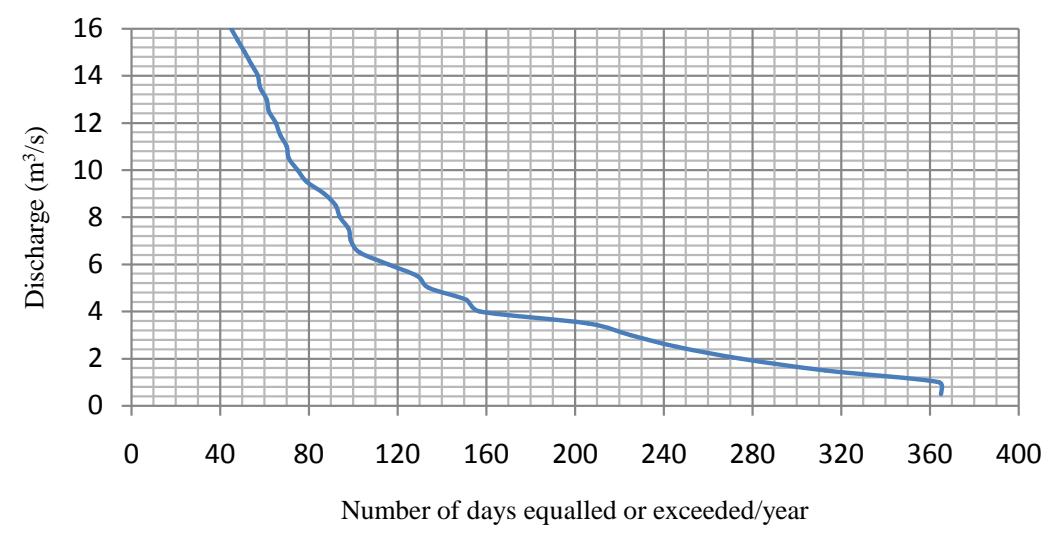

Figure 4. Graded flow curve.

engineering) will give more precision to the dam structure, fore bay and tailrace and power house dimensions in a timely manner.

The penstock: The length of the penstock can be between 10 to $15 \mathrm{~m}$. then for the PVC material, $D_{p}=0.38 \mathrm{~m}$. The diameter of the pipe of $0.40 \mathrm{~m}$ available on the market can be considered. Then the minimum thickness of penstock $t_{p}=2$, $47 \mathrm{~mm}$.

The turbine: According to the Sulzer-Escher Wyss diagram the corresponding turbine is Francis turbine. The nominal power of the turbine is $97 \mathrm{~kW}$. Let's consider a turbine of a nominal power of $100 \mathrm{~kW}$.

The generator: A generator synchronous of frequency $50 \mathrm{~Hz}$.

The technical characteristics of that MHPP projection, obtained from our study, are summarized in the following Table 1.

\subsubsection{The Legal and Regulatory Framework}

According to the rules of safety, environmental and protection (Section 60: 1 of law $n^{\circ} 022 / 2011$ ) [11], the legal regime is a simple declaration to do and the competent institution is the Electricity Sector Regulatory Board (ARSEL). No special requirements for tender notices or advertisement shall be imposed.

\subsubsection{Economic Analysis}

\section{1) Investment cost}

A recent other assessment done in KEMKEN river gives lots of orientations [7]. The investment cost of MHPP varies from a site to another. The following Table 2 shows the cost investment estimation of MHPP of BAKASSA.

\section{2) Operating forecasts}

In Cameroon, the prize of electricity in social range is 50 FCFA per kWh. In that locality, which is a rural area, the consumption of each household will be in social range. If the producible is equal to $850 \mathrm{MWh}$, as calculated previously, considering a MHPP's utilization rate of $60 \%$ for our evaluation. Then, the annual Cash flow is $C F_{i}=25,491,600$ FCFA.

\section{3) Operating expenses}

There are local blacksmiths whom were manufacturing micro turbines and some spare parts for MHPP in the West Region of Cameroon [12]. Then, maintenance 
Table 1. Technical data of the project.

\begin{tabular}{|c|c|}
\hline Sizes & Values \\
\hline \multicolumn{2}{|c|}{ Site characteristics } \\
\hline Gross head & $4 \mathrm{~m}$ \\
\hline Mean flow rate & $9.72 \mathrm{~m}^{3} / \mathrm{s}$ \\
\hline Minimum flow rate & $0.503 \mathrm{~m}^{3} / \mathrm{s}$ \\
\hline \multicolumn{2}{|c|}{ Turbine } \\
\hline Type & Francis \\
\hline Rotation speed & $375 \mathrm{tr} / \mathrm{min}$ \\
\hline Net head & $4 \mathrm{~m}$ \\
\hline Nominal flow rate & $2.9 \mathrm{~m} 3 / \mathrm{s}$ \\
\hline Nominal power & $100 \mathrm{~kW}$ \\
\hline \multicolumn{2}{|c|}{ Alternator } \\
\hline Type & Synchronal \\
\hline Tension & $380 / 220 \mathrm{~V}$ \\
\hline Frequency & $50 \mathrm{~Hz}$ \\
\hline \multicolumn{2}{|c|}{ Interconnection/distribution } \\
\hline Type of grid & Isolate \\
\hline \multicolumn{2}{|c|}{ Production of electricity } \\
\hline Producible & $850 \mathrm{MWh}$ \\
\hline
\end{tabular}

Table 2. The MHPP investment budget in FCFA.

\begin{tabular}{clc}
\hline $\mathbf{N}^{\bullet}$ & \multicolumn{1}{c}{ Component of the MHPP } & Total Price (FCFA) \\
\hline 1 & Civil engineering works: Total 1 = T1 & $\mathbf{4 3 , 1 2 5 , 0 6 2}$ \\
2 & Metal construction: Total 2 = T2 & $\mathbf{1 , 7 0 0 , 0 0 0}$ \\
3 & Turbo-generator group: Total 3 = T3 & $\mathbf{1 8 , 7 7 5 , 0 0 0}$ \\
4 & Equipment for transmission and supply of electricity: Total 4 = T4 & $\mathbf{9 , 8 0 0 , 0 0 0}$ \\
Others cost (administration and legal fees): Total 5 = T5 & $\mathbf{7 , 0 0 0 , 0 0 0}$ \\
Total = T1 + T2 + T3 + T4 + T5 & $\mathbf{8 0 , 4 0 0 , 0 6 2}$ \\
Contingences 10\% = I & $\mathbf{8 , 0 4 0 , 0 0 6}$ \\
Grand Total & $\mathbf{8 8 , 4 4 0 , 0 6 8}$
\end{tabular}

1 Euro $=656$ FCFA.

will be in low cost. In that case, let's consider that the direct costs represent 30\% of the cash-flow. The rate of inflation in Cameroon in 2016 was about 3\%. The discount rate in Cameroon about is $12.5 \%$ [13].

4) Estimated profitability

a) Net present value NPV

Considering all these information about the operating cost, if the deadline of 
project is 20 years, then the $N P V$ of that project is equal to: $N P V=29,441,430$ FCFA.

Since the net present value is positive. So, the project is profitable with the hypothesis took in account.

\section{b) The project payback period (PBP)}

The calculation of the payback period is: $\mathrm{PBP} \approx 8$ years +2 months.

\subsection{Discussion}

It is important to say that $97 \mathrm{~kW}$ cannot solve all the electricity problem of that locality in long term. But actually, the population of BAKASSA mainly needs electricity for lighting, the charge of telephones, the supply of radios and televisions and some transformations of agricultural products (cassava, maize...). Let's remind that, Lomé and Katmandou conferences in 1979 had presented the possibility to feed around one hundred households (in rural area) with $30 \mathrm{~kW}$ [8]. Considering also the fact that energy produced from MHPP is renewable, the MHPP of BAKASSA can help to improve the live quality of the population in that village and therefore contribute to their sustainable development.

Solar energy for photovoltaic can also be studied and integrated gradually for a more effective coverage of the long term electricity demand. But at least for the next ten years after the implementation of that project, the population will not have any problem of electricity. The project is profitable but, the lack of funding can be a constraint.

\section{Conclusions}

The aim of this work was the technical and economic assessment of the project of MHPP in the waterfall of BAKASSA.

It emerges that the development of the BAKASSA MHPP will be an example of the contribution of renewable energies to the sustainable development of that locality. Considering the hydrological data of the river, the installed power is 97 $\mathrm{kW}$ for an isolate network. A Francis turbine is recommended for its equipment. The investment cost of this project is $88,440,068$ FCFA. It is a profitable project and the maximum payback period is 9 years. The lack of funding in Cameroon can be the main constraint to the development of that MHPP.

Solar energy for photovoltaics can also be studied and integrated gradually for a more effective coverage of the long term electricity demand.

\section{References}

[1] Report Lighting Africa (2012) Report of Cameroon Politic Lighting Africa.

[2] Nasir, A.B. (2014) Design Considerations Micro-Hydro-Electric-Power Plant. Energy Procedia, 50, 19-29. https://doi.org/10.1016/j.egypro.2014.06.003

[3] Pagès, J.M., Supparo, E., Lafage, B., Etienne, J., Valet, T. and Galiano, M. (2003) Guide pour le Montage des petites Hydroélectricité. [Small Hydro Power Plant Project Guide.] ADEME.

[4] Anonymous (2013) Micro-Hydro Power. 
http://www.rowan.edu/colleges/engineering/clinics/cleanenergy/rowanuniversitycleanenergy program/EnergyEfficiencyAudits/EnergyTechnologyCaseStudies/files/MicroHydroPower.pdf

[5] Kengne. W.V. (2008) Du costume de la confrérie Kuingang de Bansoa à la création picturale: Proposition d'œuvres plastiques. [From the Kuingang Association of Bansoato the Pictorial Creating: Plastics Art Proposition.] University Yaoundé 1, Yaoundé.

[6] Center for Maritime and Fluvial Technical Studies (2012) Microcentrales hydroélectriques, Note de synthèse. [Hydroelectric Power Plants, Executive Summary.] Ministry of Ecology of Sustainable Development, Transport and Housing in France.

[7] Kengne Signe, E.B., Hamandjoda, O. and Nganhou, J. (2017) Methodology of Feasibility Studies of Micro-Hydro Power Plants in Cameroon: Case of the Micro-Hydro of KEMKEN. Energy Procedia, 119, 17-28. https://doi.org/10.1016/j.egypro.2017.07.042

[8] Tekounegning (2010) Feasibility study of de MHPP in the Ouest Region of Cameroon. [Feasibility Study of the MHPP in the West Region of Cameroon.] Doctorat/Ph.D. Thesis, University of Dschang, Yaoundé.

[9] Linsley, R.K. and Franzini, J.B. (1972) Water-Resources Engineering. 2nd Edition, McGraw-HillBook Company, New York.

[10] Institute of Geological and Mining Research (1985) Tableau des débits moyens journaliers, Choumi et Metchié. [Table of Average Daily Flows, Choumi and Metchié.] Hydrological Yearbook of the Republic of Cameroon of the Year, 45-47.

[11] Loi $n^{\circ}$ 2011/022, (14/12/2011) Loi régissant le secteur de l'électricité. [Law Governing the Electricity Sector in Cameroon.]

[12] Elie B, K.S., Tekounegning, Hamandjoda, O. and Nganhou, J. (2015) Local Blacksmiths's Activity in the West Region of Cameroon and Their Contribution to the Development of Micro Hydroelectric Power Plants in That Region. African Journal of Environmental Science and Technology, 9, 428-437. https://doi.org/10.5897/AJEST2014.1798

[13] National Institute of Statistics (INS) (2016) Note de synthèse de l'Evolution de l'inflation au cours des neufs premiers mois de l'année. [Brief Summary of Inflation over the First Nine Months of the Year.] http://www.statistics-cameroon.org

Submit or recommend next manuscript to SCIRP and we will provide best service for you:

Accepting pre-submission inquiries through Email, Facebook, LinkedIn, Twitter, etc. A wide selection of journals (inclusive of 9 subjects, more than 200 journals)

Providing 24-hour high-quality service

User-friendly online submission system

Fair and swift peer-review system

Efficient typesetting and proofreading procedure

Display of the result of downloads and visits, as well as the number of cited articles

Maximum dissemination of your research work

Submit your manuscript at: http://papersubmission.scirp.org/

Or contact jpee@scirp.org 